\title{
The Spiritual Bypass Scale-Brazilian Adaptation: How Religious Affiliation, Age, and Gender Can Predict Levels of Psychological Avoidance and Spiritualizing
}

\author{
Gabriela Picciotto ${ }^{1}$ Jesse Fox ${ }^{2}$ \\ University of Porto Stetson University \\ Craig S. Cashwell ${ }^{3}$ \\ University of \\ North Carolina at \\ Greensboro \\ Félix Neto ${ }^{4}$ \\ University of Porto
}

\begin{abstract}
The purpose of this article is to present and discuss three validation studies of the Spiritual Bypass Scale-13 (SBS-13) on a sample of the Brazilian population. These studies have three purposes (a) to recover the twofactor solution of the SBS-13 among a Brazilian population sample; (b) understand how religious affiliation, age, and gender can predict levels of psychological avoidance and spiritualizing; and (c) explore the relationships between spiritual bypass and psycho-social variables, which include depression, anxiety, stress, narcissism, and preference for solitude. All data have been collected using an online self-report survey, and the pre-requisites for filling out the questionnaire are: (a) Brazilian citizenship, (b) a minimum of 18 years of age, and (c) ascribing to some form of spirituality or religion. Based on two different samples of the Brazilian population $\left(N_{1}=193\right.$ and $\left.N_{2}=729\right)$ that follow, the studies evidence acceptable reliability and validity of the Spiritual Bypass Scale-Brazilian Translation (SBS-BT) for use in the Brazilian Portuguese-speaking community. Using confirmatory factor analysis, we have successfully replicated a two-factor structure of the SBS-BT while controlling for the effects of age, gender, and religious affiliation. The model replicates the two-factor structure of the Brazilian version of the SBS with indications of good fit: $X_{(49, N=729)}^{2}=190.9, p<$. 001; $C M I N / d f=3.89 ; C F I=.95$, SRMR $=.04$, RMSEA $=.06$. All items load onto two factors with coefficients ranging from .49 to .65 . Alpha coefficients range from .72 to .86 across the two different samples. Results show a significant multivariate effect for religious affiliation and spiritual bypass. The dimensions of spiritual bypass predict the variances in stress, anxiety, and depression. For depression and anxiety, spiritualizing adds a unique, predictive value over and above the demographic variables and superiority (facet of narcissism).
\end{abstract}

Keywords

Spiritual bypass $\bullet$ Scale adaptation $\bullet$ Confirmatory factor analysis $\bullet$ Stress $\bullet$ Anxiety $\bullet$ Depression

1 Correspondence to: Gabriela Picciotto, Faculdade de Psicologia e de Ciências da Educação da Universidade do Porto. Address: Porto, Portugal. Rua da Venezuela, 227, Hab. 2.302, Porto, Portugal. Zip Code: 4150-744. Email: up201608739@fpce.up.pt \& gabipicciotto@theusnjar.com

2 Jesse Fox, Department of Counselor Education, Stetson University.

3 Craig S. Cashwell, Department of Counseling and Educational Development, University of North Carolina at Greensboro.

4 Félix Neto, Faculdade de Psicologia e de Ciências da Educação da Universidade do Porto, Porto, Portugal.

Citation: Picciotto, G., Fox, J., Cashwell, C. S., \& Neto, F. (2018). The Spiritual Bypass Scale-Brazilian Adaptation: How religious affiliation, age, and gender can predict levels of psychological avoidance and spiritualizing. Spiritual Psychology and Counseling, 3, 23-46. http://dx.doi.org/10.12738/spc.2018.1.0034 


\section{Manevi Geçiştirme Ölçeği-Brezilya Adaptasyonu: Dinî İnanç, Yaş ve Cinsiyetin Psikolojik Kaçınma ve Manevileştirme Düzeylerini Yordaması}

\author{
Gabriela Picciotto \\ Porto Üniversitesi
}

\author{
Jesse Fox \\ Stetson Üniversitesi
}

\author{
Craig S. Cashwell \\ North Carolina \\ at Greensboro \\ Üniversitei
}

\author{
Félix Neto \\ Porto \\ Üniversitesi
}

Öz

Bu makalenin amacı, Brezilyalı bir örneklem üzerinde Manevi Geçiştirme Ölçeği-13’ün (SBS-13) geçerlik ve güvenirliğine ilişkin üç çalışmayı sunmak ve tartışmaktır. Bu çalışmaların üç amacı vardır: a) Brezilyalı bir örneklemde SBS-13'ün iki faktörlü çözümünü ortaya çıkarmak; (b) dini eğilimin, yaşın ve cinsiyetin psikolojik kaçınma ve manevileştirme seviyelerini nasıl yordadığını incelemek ve (c) manevi geçiştirme ile depresyon, anksiyete, stres, narsisizm ve yalnızlık tercihini içeren psiko-sosyal değişkenler arasındaki ilişkileri araştırmak. Tüm veriler çevrimiçi bir öz-bildirim anketi kullanılarak toplanmıştır ve anketin doldurulmasına yönelik önkoşullar şunlardır: (a) Brezilya vatandaşlı̆̆ı, (b) en az 18 yaşında olmak ve (c) din veya maneviyatın bir türüne ilişkin bağlılık. Brezilyalı iki farklı örneklem üzerinde yapılan çalışmalarda $\left(N_{1}=193\right.$ and $\left.N_{2}=729\right)$ Brezilya Portekizcesi konuşan bireylerde kullanılmak üzere uyarlanan Manevi Geçiştirme Ölçeği- Brezilya Formu'nun kabul edilebilir düzeyde güvenirlik ve geçerlik özelliklerine sahip olduğu kanıtlanmıştır. Doğrulayıcı faktör analizi kullanılarak, SBS-13'ün iki faktörlü yapısı, yaş, cinsiyet ve dini eğilimlerin etkileri kontrol edilerek başarıyla doğrulanmıştır. $\mathrm{Bu}$ model, SBS'nin Brezilya versiyonunun iki faktörlü yapısını, iyi uyum göstergeleriyle tekrarlamıştır $X^{2}{ }_{(49, \mathrm{~N}=729)}=190.9, \mathrm{p}<$. 001; $C M I N / d f=3.89 ; C F I=.95$, SRMR $=.04$, RMSEA $=.06$. Tüm maddeler, .49 ila .65 arasında değissen katsayılarla iki faktöre yüklenmektedir. Alfa katsayıları iki farklı örneklemde .72 ila .86 arasındadır. Sonuçlar, dini eğilim ve mane-vi geçiştirmenin anlamlı düzeyde bir çok değişkenli etkisi olduğunu göstermektedir. Manevi geçiştirmenin boyutları stres, anksiyete ve depresyondaki varyansları yordamaktadır. Depresyon ve anksiyete için, manevi-leştirme; demografik değişkenler ve üstünlük (narsisizm boyutu) değisskeninden farklı ve bu değişkenlerin üzerinde özgül bir yordayıcı etki katmaktadır.

\section{Anahtar Kelimeler}

Manevi geçiștirme • Ölçek uyarlama • Doğrulayıcı faktör analizi • Stres • Anksiyete • Depresyon 
The term spiritual bypassing first surfaced in the literature in 1984 with the publication of an article in Transpersonal Psychology called, "Principles of Inner Work: Psychological and Spiritual" by John Welwood. In this article, Welwood retold the story of his formation within Eastern religion and his subsequent contact with Western psychology. After a period of paying close attention to how members of spiritual groups interact with each other and navigate developmental tasks, he noticed a problematic phenomenon:

I started to pay more attention to a disturbing tendency among certain members of spiritual communities. Although many of these spiritual practitioners were doing very good work on themselves - which I bow to and respect as extremely important — still some of them seemed to be using meditation or their spiritual involvements to bypass certain kinds of personal emotional "unfinished business." There is a certain temptation, which I can observe in myself as well, to try to use spiritual practice to rise above the difficulties of unresolved personal problems and emotions... I have come to call this tendency to try to avoid or prematurely transcend basic human needs, feelings, and developmental tasks "spiritual bypassing." (p. 64)

Since Welwood first published his observation of his Buddhist communities, the term later has surfaced in the addiction field where Whitfield (2003) noticed a tendency for recovering addicts, once they had become acquainted with spiritual practices such as the 12-Step Program, to try and avoid doing important psychological work related to their mental illness by trying to be spiritually advanced. Various definitions exist in the literature to describe spiritual bypass, from the straightforward "premature transcendence" (Whitfield, 2003, p. 119) to the more nuanced "defensive psychological posture cultivated by a tendency to privilege or exaggerate spiritual beliefs, emotions, or experiences over and against psychological needs creating a means of avoiding or bypassing difficult emotions or experiences" (Fox, Piccioto, \& Cashwell, 2017, p. 2). Despite the differences in how spiritual bypass may be defined, a common element to these descriptions is that they emphasize avoidance, in this case avoiding painful experiences (or potentially painful experiences) by exercising spirituality.

Though the name spiritual bypass is relatively new when considering the century old tradition of the psychology of religion and spirituality, the psychological process it describes is anything but new. The so-called masters of suspicion-Marx, Nietzsche, and Freud - all evaluated religious and spiritual experience through a hermeneutic of suspicion and interpreted that these masked more basic psychological drives for money, power, and sex (Ricoeur, 1970). Though more contemporary scholars of the psychology of religion and spirituality have largely discredited such hyper-criticism (Koenig, 2012; Pargament, 2011; Piedmont, 1999), others have acknowledged and worked at great length to describe religious and spiritual processes that can vary from mildly discomforting to ultimately harmful for human psychology and spirituality (Griffith, 2010). Likewise, scholars who have written about spiritual bypass in either theoretical, applied, or empirical contexts consistently agree that spiritual bypass poses real and significant problems for both spiritual and psychological growth. 
At the same time, what differentiates voices within the tradition of the hermeneutic of suspicion to experts of spiritual bypass is the way spirituality is ultimately conceptualized. For the masters of suspicion (and those who carry their banner today), spirituality is reduced to mere illusions of our consciousness and viewed as a mask or substitute for some better explained psychological drive. In contrast, scholars of spiritual bypass maintain that spirituality is a non-reductive phenomenon that can be authentic and life-giving. In this way, the way theoreticians describe spiritual bypass shares some commonality with Pargament's (1988) factor of deferring problemsolving in which personal responsibility is abdicated in favor of a divine problemsolver. For Pargament, the primary difference apparently is that deferral problem solving may be entirely appropriate for certain issues (e.g., chronic illness with no chance of medical intervention). In spiritual bypass, a heavier emphasis is placed on avoidance; that is, using spirituality to sidestep difficult experiences. Though spiritual bypass is probably in the most positive sense a coping strategy (or perhaps more negatively framed as a defense) and a way that prevents people from feeling the overpowering effects of unbearable suffering, it is nevertheless viewed as a temporary solution and ultimately an obfuscation of authentic spirituality.

\section{A New Measure of Spiritual Bypass}

Though several articles, chapters, and one book have surfaced over the years since Welwood (1984) first coined the term, most of the literature about spiritual bypass has remained theoretical or practical. Only one team of researchers has attempted to empirically substantiate a theoretical model of spiritual bypass (Cashwell, Glosoff, \& Hammonds, 2010). In that same time, research on spirituality and its relationships to many facets of holistic health and wellbeing has only accelerated (Koenig, 2012). However, research on spiritual bypass has remained stagnant since 2010 with no empirical studies having been published in roughly a seven-year period. This is somewhat surprising since experts have argued that clinicians' being conversant with the nuances of spiritual bypass to be vitally important as many people's pursuit of a spiritual path or being religiously committed to both Eastern and Western traditions is a common experiene (Cashwell, et al. 2004; Masters, 2010; Welwood, 1984). Moreover, clinicians have attested to the serious problems that spiritual bypass poses for social, psychological, and spiritual health; among the complications it could pose include depression, anxiety, addiction, stagnated emotional maturity or alexithymia, isolation, and spiritual narcissism (Cashwell et al., 2007; Cashwell et al., 2010; Clarke, Giordano, Cashwell, \& Lewis, 2013; Welwood, 2000; Whitfield, 2003). Given such postulations and its supposed widespread prevalence, research on spiritual bypass is sorely needed. 
Despite the escalating interest in empirically studying spirituality in health contexts, however, the research investigating spiritual bypass has failed to keep pace, owing primarily to the simple fact that no instruments have existed that measure it. In response, Fox, Cashwell, \& Picciotto (2017) developed The Spiritual Bypass Scale-13 (SBS-13) to provide a solid foundation and direction to the social scientific study of spiritual bypass. Using a norming sample of 661 participants drawn from the general public in the United States, the sample was diverse across religious affiliation and racial identification approximating national norms. Exploratory factor analysis (EFA) of the scale and subsequent confirmatory factor analysis (CFA) supported a two-factor structure of the SBS-13 with a second-order factoring. The first factor, Psychological Avoidance, encapsulated a "process of sidestepping or avoiding difficult emotions, experiences, or circumstances through spiritual beliefs or assumptions" (p. 10). Spiritualizing, the second factor, included items indicative of "appraising ordinary scenarios and exaggerating their spiritual significance" (p. 10). They also tested the predictive capacity of the scale on measures of psychological distress (depression, anxiety, and stress) and religious crisis and found that spiritual bypass can predict such psycho-spiritual problems. However, how spiritual bypass relates to these experiences is anything but straightforward. For instance, they found scores for psychological distress to be inversely related to Psychological Avoidance and Spiritualizing. Moreover, these two facets of spiritual bypass also predicted beta weights (units of measure) in opposite directions, which helps explain why spiritual bypass can be so emotionally stunting.

The first validation study of the SBS-13 provided interesting and thought provoking results that can help carry the study and application of spiritual bypass forward to a new stage, yet many questions remain unexplored. Chief among these questions is the cultural variability (age, gender, religious affiliation, nationality, or language) that could influence scores on the scale. What is to say that spiritual bypass is mostly limited to Western or English speaking populations? Does spiritual bypass stay stable with age or does it escalate? De-escalate? Because women tend to score higher on spirituality measures than men (Piedmont, 2010), is the same true for spiritual bypass? Does spiritual bypass exist in equal proportions within religious subgroups, or are some groups more or less prone to fall into its trappings? To answer such questions, we have conducted three studies to validate the SBS-13 on a sample of the Brazilian population. In the first study, we translate the scale into Brazilian Portuguese and examine the factor structure of the scale. In the second study, we replicate the factor structure on a new sample of Brazilian participants and test for the effects of age, gender, and religious affiliation on the scores for spiritual bypass. In the third and final study, we test the relationships between the revised version of the scale and the measures of psychological distress, preference for solitude, and narcissism. 


\section{Study 1: Scale Translation and Cross-Cultural Validation}

The purpose of this study is to adapt the Spiritual Bypass Scale (SBS-13) and replicate the factor structure on a sample of the Brazilian population.

\section{Method}

\section{Participants}

The participants consist of 193 individuals ( $88.6 \%$ females) between the ages of 18 and 75 years $(M=36.8, S D=11.3)$. In terms of race, $155(80.3 \%)$ are Caucasian, 30 (15.5\%) are Pardo (Brazilians of mixed ethnic ancestries, typically a mixture of white Brazilian, Afro-Brazilian, and Native Brazilian), seven (3.6\%) are Black and one $(0.5 \%)$ is Asian. Regarding religion affiliation, 79 (40.9\%) are Christian, 75 (38.9\%) are spiritual but not religious, $28(14.5 \%)$ are Spirits, three (1.6\%) are Umbandists, 2 $(1.0 \%)$ are Buddhist, one $(0.5 \%)$ is Hindu, and five (2.6) classify themselves as other.

\section{Instrument}

The Spiritual Bypass Scale-13 (SBS-13). The Spiritual Bypass Scale-13 (Fox et al., 2017) is a 13-item instrument made up of two correlated dimensions that measure spiritual bypass. Participants read various statements related to spirituality and psychological experiences and then rate to what extent that statement is true for them on a four-point Likert-type scale. The first dimension, Psychological Avoidance, includes nine items that reflect a tendency to avoid difficult psychological experiences or emotions by focusing on spirituality. An example item from this subscale includes "It is more important to me to seek spiritual guidance than to seek aid from a psychological helper." Spiritualizing is made up of four items that represent a tendency to over-emphasize spiritual explanations to difficult experiences. An example item of this subscale includes "When someone I know is experiencing hardship, I believe that it is due to spiritual attack/oppression." In the original scale-validation study, the authors conducted an exploratory factor analysis on 22 items using a sample of 348 participants in the general population of the US, from which nine items were winnowed into the two identified factors. The revised 13-item version of the scale was sent to a second sample of 313 participants from the general population of the US to study the factor replicability of the scale using confirmatory factor analysis. The results provided evidence of reasonably good fit to the data using multiple fit indices $\left(\chi_{(62, N=313)}^{2}=232.47, p=.001\right.$; Chi-Square Minimum $[C M I N] / d f=3.75$; comparative fit index $[C F I=.94)$. The alpha reliabilities in the two samples range from .75 to .87 , suggesting that the items remain consistent despite different samples collected. In addition, the convergent, discriminant, predictive, and incremental validity of the SBS13 were assessed using several criterion variables, including measures of spirituality, 
religiosity, religious-problems solving style, mindfulness, stress, anxiety, depression, and the Five-Factor Model of Personality. Though a complete re-description of the findings is beyond the scope of the present article, some findings are important to note for the purposes of the present investigation. First, spiritual bypass is strongly correlated with the measures of both spirituality and religiosity, suggesting that people who endorse higher levels of both are more likely to also endorse items that describe spiritual bypass as true for them as well. This is consistent with previous literature suggesting that spiritual bypass is uniquely situated in these populations. Second, spiritual bypass was significantly related to depression, anxiety, and stress with modest correlations. However, the two dimensions of spiritual bypass uniquely relate to these psychological problems. For instance, Psychological Avoidance relates negatively to depression while Spiritualizing relates positively to Stress and Anxiety. This suggests that, much like other coping mechanisms, spiritual bypass may have both adaptive and maladaptive qualities. Lastly, the SBS-13 was able to predict these psychological maladies even after taking into account participant's self-endorse personality styles using the Five Factor Model of Personality. The current study builds upon the initial findings of the first validation study by expanding the scope of the norming sample to an international and multilingual population.

\section{Procedure}

After receiving permission from the authors and gaining approval from the Institutional Review Board to conduct human subject research, the Spiritual Bypass Scale-13 (Fox et al., 2017) was translated into Brazilian Portuguese using the guidelines established by Borsa, Damásio, and Bandeira (2012) to ensure the linguistic, cultural, and metric equivalence of the concepts under analysis. The original 13 items of the SBS were first translated from the English language into Brazilian Portuguese by two independent translators - the first author and a bilingual expert with expertise in psychology and spirituality-who are fluent in both languages. During the translation process, refinements were made in how English statements were expressed in Portuguese until an acceptable questionnaire was developed, the two versions compared, and a single version created. This single version was administered to five Brazilians (two males and three females not included in the main study. This group was chosen following the same pre-requisites of the main study that are described below) to assess whether the terms used were linguistically clear to the respondents. All of them reported a clear understanding and acceptance of the translated items on the scale. Finally, two bilingual experts who had no previous knowledge of the SBS-13 original scale, made two independent back-translations of all scale items. These two versions also were compared, combined in a single, final, consensual version, shared with a group of four people bilingual in both English and Portuguese (two males, two females not included in the main study, and neither in the 
first test group) for a correlation analysis between the original form and the adapted one, and finally shared with the original SBS's authors for final approval.

Once the final version of the scale was approved, information about the study and invitation to participate, including the online link to the questionnaire, were posted on Facebook group pages using the snow-ball sampling procedure through participant recommendations. All data were collected through an online self-report survey, and the pre-requisites for filling out the questionnaire are: (a) Brazilian citizenship, (b) a minimum of 18 years of age, and (c) ascribing to some form of spirituality or religion.

\section{Data Analysis}

The final translated version of the SBS was subjected to confirmatory factor analysis (CFA) using AMOS 21. Before submitting the scale to CFA, we checked if the data set met all statistical assumptions for CFA, including (a) no missing values or outliers and (b) normality (Ullman, 2001).

\section{Results}

Data screening revealed no missing data and no extreme outliers (i.e., values greater than $3 S D$ s from the mean). While testing univariate normality, skewness and kurtosis values were calculated for each item. All 13 items exhibited skewness (between -1 and +1 ) and kurtosis (between -2 and +2 ) within acceptable limits (Gravetter \& Wallnau, 2014). Regarding multicollinearity, the Variance Inflation Factor $(V I F)$ and tolerance values were calculated; VIF values were between 1.276 and 2.102, and tolerance values between .476 and .826 , suggesting lack of multicollinearity between values. After ensuring the assumptions, we first tried to replicate the same factor structure from the original scale (Fox et al., 2017). Thus, the first model we tested was made up of two latent factors (Psychological Avoidance and Spiritualizing) correlated to a second order factor (Spiritual Bypass). However, the data did not provide a good fit for the model. First, we realized that Item 1 from the scale, a reversed-scored item, didn't perform well $\left(\chi_{(65, N=193)}^{2}=303.11, p<.001 C M I N / d f=4.66 ; C F I=.71, S R M R=.23\right.$, RMSEA = .14.) and so we decided to take the item out of the second model and covaried four items (Item 3 to Item 4 and Item 12 to Item 13) to improve model fit. The second model, however, also did not perform adequately $\left(\chi_{(52, N=193)}^{2}=187.53, p<.001\right.$ $C M I N / d f=3.61 ; C F I=.83, S R M R=.22, R M S E A=.12)$. In the creation of the original scale, the authors presented an alternative factor structure leaving out the second order factor. Given that both of the first order factors in our study demonstrated a high level of correlation with the second order factor (.95 and .96), we decided to subject the data in the third model to a CFA testing only for the two-factor structure and dropped the second-order factor from the analysis. We had the same problem with Item 1 as we did in Model 1 (above), which was removed, and the errors terms for three items (Item 3 to 
Item 4 and Item 4 to Item 6) were co-varied to improve the model fit. Correlating these error terms was theoretically consistent to their content as all of them targeted painful events where a divine figure intervened to solve a difficulty This final model replicated the two-factor structure of the SBS-13 with indications of reasonably good fit: $\chi^{2}{ }_{(51, N=}$ ${ }_{193)}=108.14, p<.001 ; C M I N / d f=2.12 ; C F I=.92, S R M R=.06, R M S E A=.08$. All the items loaded onto the two factors, with values ranging from .45 to .74 . Cronbach alpha coefficients also were calculated for the total scale and for both subscales. These alphas (Total Scale, $\mathrm{a}=.86$; Psychological Avoidance, $\mathrm{a}=.83$; Spiritualizing, $\mathrm{a}=.73$ ), closely matched the original alphas of the SBS-13 validation sample.

Table 1

Study 1 - Confirmatory Factor Analysis Results

\begin{tabular}{lccccccc}
\hline & $\chi^{2}$ & $d f$ & $p$ & $C M I N / d f$ & $C F I$ & SRMR & RMSEA \\
\hline $\begin{array}{l}\text { Model with Item 1 and 2nd-order factor } \\
\begin{array}{l}\text { Model without Item 1 and with 2nd-order } \\
\text { factor }\end{array}\end{array}$ & 183.11 & 65 & $<.001$ & 4.66 & .71 & .23 & .14 \\
$\begin{array}{l}\text { Model with 2 factor structure and no 2nd-order } \\
\text { factor }\end{array}$ & 52 & $<.001$ & 3.61 & .83 & .22 & .12 \\
\hline
\end{tabular}

Note: $N=193$

\section{Study 2: Factor Replication of the Spiritual Bypass Scale-Brazilian Translation and Potentially Confounding Effects}

In Study 1, a Brazilian version of SBS-13 with a two-factor structure was identified. However, to approximate a model with strong enough fit indices, we had to shorten the scale to 12 items by removing Item 1 from the original instrument. We now refer to this revised version of the SBS-13 as the Spiritual Bypass Scale-Brazilian Translation (SBSBT). Thus, the purpose of Study 2 is (a) to test the factor replicability of the SBS-BT on a new sample of Brazilian participants and (b) to explore how differences in demographic profiles (age, gender, and religious affiliation) can affect scores on the SBS-BT.

\section{Method}

\section{Participants}

The participants consist of 729 individuals (82.4\% females) aged between 18 and 94 years $(M=40.4, S D=12.5)$. All participants voluntarily agreed to participate in the study. In terms of race, $583(80.0 \%)$ are Caucasian, 105 (14.4\%) are Pardo (Brazilians of mixed ethnic ancestries, typically a mixture of white Brazilian, Afro-Brazilian and Native Brazilian), 25 (3.4\%) are Black, 15 (2.1\%) are Asian, and one $(0.1 \%)$ is Indian. Regarding religious affiliation, 342 (46.9\%) are spiritual but not religious, 172 (23.6\%) are Christian, 112 (15.4\%) are Spirits, 19 (2.6\%) are Buddhist, 17 (2.3\%) are Umbandists, $3(0.4 \%)$ are Jewish, and 64 (8.8\%) classified themselves as "other." 


\section{Instrument}

Participants completed the SBS-BT refined from Study 1. However, we decided to use all 13 items of the original scale to test if the new sample would also suggest that Item 1 performs poorly in the Brazilian culture.

\section{Procedure}

All data have been collected using an online self-report survey, and the prerequisites to participate in the study are: (a) Brazilian citizenship, (b) a minimum of 18 years of age, and (c) ascribing to some form of spirituality or religion. Information about the study, invitation to participate, and the online link for the questionnaire were sent by email to a 15,000-person mailing list from the first author's blog. A total of 3,631 opened the email and 729 people participated in the study. We collected all IPs addresses from participants of Studies 1 and 2 to ensure that we had not recruited the same sample participants from Study 1.

\section{Data Analysis}

With the objective of exploring all the objectives of Study 2, the data analysis processes are composed of three different steps.

Confirmatory factor analysis. The refined version of the scale was subjected to CFA using AMOS 21. As in Study 1, before submitting the scale to the CFA, we checked if the data set fulfilled all assumptions for CFA, including (a) no missing values or (b) outliers and that (c) the scores are normally distributed (Ullman, 2001). Data screening revealed no missing data and no extreme outliers (i.e., values greater than 3 SDs from the mean).

Structural invariance. We were interested in testing for the structural invariance of the SBS-BT of the two-factor structure achieved in Study 2 CFA in consideration of possible variations from gender, age, and religious affiliation. Again using CFA in Amos 24, we tested both the unconstrained (configural invariance) and constrained (metric invariance) models.

Age, gender, and religious affiliation effects. To compare how age, gender, and religious affiliation can predict the scores for Psychological Avoidance and Spiritualizing, we first conducted a hierarchical regression testing for the associations of age (linear), its square (quadratic), and cube (cubic) on the scores for Psychological Avoidance and Spiritualizing. 


\section{Results}

\section{Confirmatory Factor Analysis}

Data screening revealed no missing data and no extreme outliers. While testing univariate normality, skewness and kurtosis values were calculated for each item. All 13 items exhibited skewness (between -1 and +1 ) and kurtosis (between -2 and +2 ) statistics within acceptable limits (Gravetter \& Wallnau, 2014). The VIF and tolerance values were calculated; the VIF values are between 1.289 and 2.288, and tolerance values are between .437 and .776, which indicates a lack of multicollinearity. After checking the assumptions, we first conducted the CFA testing for the second-order factor in the new sample. As in Study 1, Item 1 did not perform well as a reverse-scored item $\left(\chi_{(65, N=729)}^{2}=1,147.78, p<\right.$ $.001, C M I N / d f=17.66 ; C F I=.66, S R M R=.24, R M S E A=.15)$, so we decided to run the CFA again without Item 1. We also co-varied terms for 10 items (Item 3 to 4, Item 5 to 6 , Item 7 to 8 , Item 8 to 9 , Item 10 to 13 , and Item 12 to 13 ) to improve the model fit; however, the model still did not perform well enough $\left(\chi_{(48, N=193)}^{2}=471.60, p<.001, C M I N / d f=\right.$ $9.82 ; C F I=.86, S R M R=.21, R M S E A=.11)$. Given that both of the first-order factors in our study demonstrated a high level of correlation with the second-order factor (.94 and .99), we decided to subject the data to CFA testing only for the two-factor structure and dropped the second-order factor from the analysis. We had the same problem with Item 1 as we did in Model 1 (above), which was removed. Errors terms for eight items (Item 3 to 4, Item 5 to 6 , Item 8 to 9, and Item 10 to 11) were co-varied to improve the model fit. All co-varied error terms are located within their assigned factor and theoretically consistent in regards to their content. Both Items 3 and 4 target painful events and claims of divine intervention in solving them, both Items 5 and 6 rely heavily on spirituality as a superior way of solving difficulties compared to other strategies, both Items 8 and 9 indicate that developing spiritually is more important than developing emotionally, and both Items 10 and 11 state that when they or someone they know is experiencing problems, it is because there is something spiritually wrong. After removing Item 1 and correlating the error terms for the above items, the model replicates the two-factor structure of the Brazilian version of SBS with indications of good fit $\left(\chi_{(49, N=729)}^{2}=190.9, p<.001 ; C M I N / d f=3.89 ; C F I=.95, S R M R=.04, R M S E A=.06\right)$. All items load on the two factors with coefficients ranging from .49 to .65 . Cronbach alpha coefficients have been calculated (Total Scale, $\mathrm{a}=.86$; Psychological Avoidance, $\mathrm{a}=.83$; Spiritualizing, $\mathrm{a}=.72$ ) and approximate the original internal consistency of the US norm population for the scale.

Table 2

Study 3 - Confirmatory Factor Analysis Results

\begin{tabular}{lccccccc}
\hline & $\chi^{2}$ & $D f$ & $p$ & $C M I N / d f$ & CFI & SRMR & RMSEA \\
\hline Model with Item 1 and 2nd-order factor & $1,147.78$ & 65 & $<.001$ & 17.66 & .66 & .24 & .15 \\
$\begin{array}{l}\text { Model without Item 1 and with 2nd-order factor } \\
\begin{array}{l}\text { Model with two-factor structure and no 2nd- } \\
\text { order factor }\end{array}\end{array}$ & 190.90 & 49 & $<.001$ & 3.89 & .95 & .04 & .06 \\
\hline
\end{tabular}

Note: $N=193$ 


\section{Structural Invariance}

The results are organized in Table 1 . We interpreted that the model fit would be noticeably worse if the CFI dropped by more than .01(Cheung \& Rensvold, 2002). Overall, the fit indices remained stable while testing the two-factor model of spiritual bypass across groups partitioned in terms of gender (male and female), age (young, middle, and elder), and religious affiliation (spiritual but not religious/traditional religion).

Table 3

Tests of Structural Invariance considering Gender, Age, and Religious Affiliation

\begin{tabular}{llcccccccc}
\hline & & $\chi^{2}$ & $d f$ & $p$ & $C M I N / d f$ & $C F I$ & SRMR & RMSEA & $\chi^{2}$ difference \\
\hline SBS-BT & & 190.95 & 49 & .000 & 3.89 & .95 & .04 & .06 & \\
Gender $^{\mathrm{a}}$ & & & & & & & & & \\
& Configural & 236.6 & 98 & .000 & 2.41 & .95 & .04 & .04 & \\
Age $^{\mathrm{b}}$ & Metric & 258.7 & 110 & & 2.35 & .94 & .04 & .05 & $.04 *$ \\
& & & & & & & & & \\
Religious Affiliation $^{\mathrm{c}}$ & Configural & 325.4 & 147 & .000 & 2.21 & .94 & .07 & .04 & \\
& Metric & 355 & 171 & .000 & 2.08 & .94 & .07 & .04 & .19 \\
& & & & & & & & & \\
& Configural & 226.4 & 98 & .000 & 2.31 & .96 & .05 & .04 & \\
& Metric & 244 & 110 & .000 & 2.22 & .95 & .05 & .04 & .13 \\
\hline
\end{tabular}

Note $:{ }^{\text {a }}$ Male $=128$, Female $=601 ;{ }^{\mathrm{b}}$ Young $=137$, Middle $=545$, Elder $=47 ;{ }^{\mathrm{s}}$ Spiritual but not Religious $=$ 342 , Religious $=387$;

$* p<.05$ indicates structural variation between groups

\section{Age, Gender, and Religious Affiliation Effects}

There was only one statistically significant effect, a significant linear association between age and Psychological Avoidance $\left(\Delta R^{2}=.008, F_{(1,727)}=6.98, p<.01\right)$. Next we conducted MANOVA using age $(N=729, n=137,18.9 \%$ between $18-29$ in age, $n=545,74.7 \%$ between $30-60$ in age, and $n=47,6.4 \%$ between $61-94$ in age) and gender $(N=729, n=601,82.4 \%$ female, $n=128,17.6 \%$ male $)$ as the independent variables and Psychological Avoidance and Spiritualizing as the dependent variables. Before running MANOVA, we ensured the data fulfilled all statistical assumptions of the analysis, including (a) no missing values or (b) outliers, (c) normal distribution of scores, and (d) homogeneity of variance matrices. Normality, missing values, and outliers were already assured for running the CFA. In terms of homogeneity of variancecovariance matrices, we used Levene's test and the statistic was non-significant $(p>$ $.05)$ for all cases. No significant multivariate effect was found for either age $\left(F_{(4,1,446)}=\right.$ $1.02, p=.395$; Wilk's $\left.\Lambda=0.994, \eta_{p}{ }^{2}=.003\right)$ and gender $\left(F_{(2,722)}=.08, p=.927\right.$; Wilk's $\left.\Lambda=1.000, \eta_{p}{ }^{2}=.000\right)$ or the interaction effect between age and gender $\left(F_{(4,1.444)}=1.26\right.$, $p=.285$; Wilk's $\Lambda=0.993, \eta_{p}{ }^{2}=.003$ ) on the dependent variables.

With the purpose of comparing the mean scores of differing religious affiliations ( $N=729, n=342,46,9 \%$ Spiritual but not religious, $n=387,53,1 \%$ Traditional religion) with the scores of Psychological Avoidance and Spiritualizing, we conducted 
MANOVA using religious affiliation as the independent variable and Psychological Avoidance and Spiritualizing as the dependent variables. A significant multivariate effect of religious affiliation $\left(\mathrm{F}_{(2,726)}=16.87, p<.001\right.$; Wilk's $\left.\Lambda=.956, \eta_{p}{ }^{2}=.044\right)$ was found on the dependent variables. Considering the effects between subjects, a significant effect of religious affiliation was found on Psychological Avoidance $\left(\mathrm{F}_{(1,727)}=33.69, p<.001 ; \eta_{p}{ }^{2}=.044\right)$. Univariate analyses indicate that people with traditional religious affiliation score significantly higher $(M=21.23)$ than spiritual but not religious people $(M=19.37)$ on Psychological Avoidance. The same is true for Spiritualizing $\left(F_{(1,727)}=11.98, p=.001 ; \eta_{p}{ }^{2}=.016\right)$. Univariate analyses indicate that people with traditional religious affiliation score significantly higher $(M=8.14)$ than spiritual but not religious $(M=7.59)$ participants on Spiritualizing.

\section{Study 3: The Relationship between Spiritual Bypass and Psycho-Social Variables}

The purpose of this study is to explore the relationship of spiritual bypass and its sub-facets with the psycho-social variables that theoretically correlate with spiritual bypass based on the existing literature (Cashwell, Bentley, \& Yarborough, 2007; Cashwell, Clarke, \& Graves, 2009; Cashwell et al., 2010; Cashwell, Myers, \& Shurts, 2004; Masters, 2010; Welwood, 1984, 2000). Once we established their relationship, we also were interested in testing the predictive value of spiritual bypass after accounting for salient control variables. Participants from Study 2 also completed the following instruments that had already been adapted to the Brazilian language, targeting those psycho-social variables we believe relate to spiritual bypass.

\section{Method}

\section{Instruments}

The Depression, Anxiety, and Stress Scale-21 (DASS-21). The Depression, Anxiety, and Stress Scale-21 (Brown, Chorpita, Korotitsch, \& Barlow, 1997; Lovibond \& Lovibond, 1995) is a 21-item measure of psychological distress. Each subscale targets common forms of psychological pathology (depression, anxiety, and stress) and provides four ordinal cut scores ranging from normal, mild, moderate, and severe, to extremely severe. This scale was adapted for a Brazilian population by Apóstolo, Mendes, and Azeredo (2006), keeping the same items and factor structure: (a) depression (Items 3, 5, 10, 13, 16, 17, 21), (b) anxiety (Items 2, 4, 7, 9, 15, 19, 20 ) and (c) stress (Items 1, 6, 8, 11, 12, 14). The average score on each subscale for the current sample was: depression $=11.2$ (mild); anxiety $=6.8$ (normal); stress $=9.0$ (normal). Thus, at the time of the study, the sample could be said to not suffer from a clinically significant level of psychological disturbance. As we used a community sample, this was theoretically expected. The alpha reliabilities for the DASS-21 
subscales in the current study are .87 (depression), .86 (anxiety), and .86 (stress). Considering previous studies (Fox et al., 2017), we hypothesize that the sub-facets of Spiritualizing will correlate positively with the three types of psychological distress, while Psychological Avoidance can possibly correlate negatively.

The Narcissistic Personality Inventory (NPI). The NPI (Raskin \& Terry, 1988) is a self-report questionnaire developed to evaluate narcissism as a personality trait. Each item is composed of a pair of narcissistic and non-narcissistic statements. Although several versions of the NPI are available, the 40-item NPI version (Raskin \& Terry, 1988) is the most widely used in surveys today and the only version adapted to a Brazilian population (Langaro, 2012). Raskin and Terry (1988) coded narcissistic statements with a score of 1 and non-narcissistic scores with a score of 0 . The participant score is the sum of marked narcissistic items ranging from 0 to 40 points; scores above 30 may be concerning, and the general average score for this scale is 15.6. The average score for the current sample is 10.4, suggesting that at the time of this study the sample self-rated as below average on indexes of narcissism. Through factor analysis, Raskin and Terry (1988) identified seven components of narcissism. These components are the partial scores corresponding to the seven subscales, namely: (a) Authority (8 items), (b) Self-sufficiency (6 items), (c) Superiority (5 items), (d) Exhibitionism (7 items), (e) Exploitativeness (5 items), (f) Entitlement (6 items), and (g) Vanity ( 3 items). The Brazilian version of the scale has only six factors with 37 items (Items 2, 6, and 22 were excluded), and these factors are not made up of the same items as the original scale. The six factors are: (a) Authority (9 items), (b) Self-sufficiency (5 items), (c) Superiority (5 items), (d) Exhibitionism (5 items), (e) Exploitativeness (6 items), and (f) Self-valorization (7 items). In this study, we work with both the original and revised factor structures. We hypothesize that Psychological Avoidance and Spiritualizing will correlate positively with Superiority as the items on this factor of narcissism closely align with a concept often associated with spiritual bypass called spiritual narcissism, a tendency to act with a high degree of arrogance as if spiritually superior (Cashwell et al., 2010). In this study, the total alpha coefficients are.79 for the English (the original scale has an alpha of .83) version and .73 for the Brazilian version (the original scale has an alpha of .77), and the alpha coefficients for the Superiority subscales are .49 (the original scale has an alpha of .54) for the English version and .47 for the Brazilian version (the original scale has an alpha of .39).

The Preference for Solitude Scale (PSS). The Preference for Solitude Scale (Burger, 1995 ) is a 12-item measure for individual's preference for solitude. In this measure, solitude refers to the absence of social interaction that can happen both by physical isolation or, in the presence of others, choosing to not interact with others (Burger, 1995). Test takers choose between two options, one reflecting a preference for solitude and the other a preference for being with other people. The scale structure has only one factor and was adapted to the Brazilian population by Testa, Rohde, and Luciano 
(2011). The Brazilian version has the same structure and items from the original scale. The participant score is the sum of items that reflect a preference for solitude; higher scores indicate a stronger preference for solitude. The general population average for this scale is 4.87 , and the current sample have scores in the above-average range at 7.28, suggesting that this sample prefer solitude more than the general population. In this study, the alpha coefficient is .77. We hypothesize that Psychological Avoidance and Spiritualizing will correlate positively with a preference for solitude, as an important feature of spiritual bypass is a tendency to avoid intimate relationships with people.

\section{Data Analysis}

Prior to analyses, we checked that the statistical assumptions for correlations and linear regressions were met. As mentioned before, the data set has no missing values or outliers, and all data meet univariate and multivariate assumptions of normality. Afterwards, we conduct a three-step process to achieve Study 3's objectives.

Correlations among measured variables. We have used bivariate correlations to determine relationships between the facets of spiritual bypass (Psychological Avoidance and Spiritualizing) to depression, anxiety, stress, superiority, and preference for solitude.

Validity study. We have conducted a series of multiple linear regressions to test the predictive capacity of Psychological Avoidance and Spiritualizing on depression, anxiety, stress, and preference for solitude (see Table 3). Each facet of the SBS was simultaneously entered as predictor variables, and the process was repeated in an iterative fashion by entering each outcome variable.

Incremental validity. We also are interested in determining if Spiritualizing has the power to predict other outcomes over and above what can be better explained by demographics variables such as age, gender, and religious affiliation, as well as other psychological characteristics such as narcissism. A perennial challenge in measuring psychospiritual constructs is to make the case that they add unique, predictive power over and above psychological control variables (Gorsuch, 1984). Accordingly, we have conducted a series of hierarchical multiple regressions using age, gender, and religious affiliation as the first block; Superiority from the Brazilian adapted NPI Scale as the second block; and Spiritualizing as the third block. This process has been repeated to predict the scores for depression, anxiety, and stress.

\section{Results}

\section{Correlations among Measured Variables}

As indicated in Table 2, Spiritualizing positively correlates with anxiety $(r=.10$, $p<.01)$, depression $(r=.10, p<.01)$, and stress $(r=.09, p<.05)$. Psychological 
Avoidance negatively correlates with preference for solitude $(r=-.09, p<.05)$ and Superiority (considering items from the original American NPI scale; $r=-.09, p<.05$ ). Regarding correlations between the psycho-social variables, the strongest correlations are for Superiority (the Brazilian NPI version) with stress $(r=.33, p<.001)$, depression $(r=-.26, p<.001)$, and anxiety $(r=.17, p<.001)$. The total narcissism score for the Brazilian NPI version also significantly correlates with stress $(r=.09, p<.05)$, as was the total narcissism score for the American version $(r=.09, p<.05)$.

Table 4

Zero-Order Correlations between Study Variables

\begin{tabular}{|c|c|c|c|c|c|c|c|c|c|c|}
\hline & Solitude & $\begin{array}{l}\text { Psychological } \\
\text { Avoidance }\end{array}$ & $\begin{array}{l}\text { Spiritual- } \\
\text { izing }\end{array}$ & $\begin{array}{l}\text { Depres- } \\
\text { sion }\end{array}$ & $\begin{array}{l}\text { Anxi- } \\
\text { ety }\end{array}$ & Stress & $\begin{array}{l}\text { EUA Su- } \\
\text { periority }\end{array}$ & $\begin{array}{c}\text { BR } \\
\text { Supe- } \\
\text { riority }\end{array}$ & $\begin{array}{l}\text { EUA } \\
\text { Total } \\
\text { NPI }\end{array}$ & $\begin{array}{c}\text { BR } \\
\text { Total } \\
\text { NPI } \\
\end{array}$ \\
\hline Solitude & - & & & & & & & & & \\
\hline $\begin{array}{l}\text { Psychological } \\
\text { Avoidance }\end{array}$ & $-.09^{*}$ & - & & & & & & & & \\
\hline Spiritualizing & -.02 & $.56^{* * *}$ & - & & & & & & & \\
\hline Depression & .06 & -.05 & $.10^{* *}$ & - & & & & & & \\
\hline Anxiety & .06 & -.02 & $.10^{* *}$ & $.68^{* *}$ & - & & & & & \\
\hline Stress & .01 & -.03 & $.09^{*}$ & $.66^{* *}$ & $.68^{* *}$ & - & & & & \\
\hline $\begin{array}{l}\text { E U A } \\
\text { Superiority }\end{array}$ & -.07 & $-.09^{*}$ & -.07 & -.06 & -.05 & .02 & - & & & \\
\hline $\begin{array}{ll}\text { B } & R \\
\text { Superiority }\end{array}$ & -.05 & -.06 & .05 & $.26^{* *}$ & $.17^{* * *}$ & $.33^{* * *}$ & $.19^{* * *}$ & - & & \\
\hline $\begin{array}{ll}\text { EUA } & \text { Total } \\
\text { NPI } & \end{array}$ & $-.11^{* *}$ & -.06 & -.05 & -.02 & -.03 & $.09^{*}$ & $.64^{* *}$ & $.38^{* *}$ & - & \\
\hline BR Total NPI & $-.12^{* * *}$ & -.05 & -.05 & -.03 & -.03 & $.09^{*}$ & $.66^{* * *}$ & $.40^{* *}$ & $.99^{* *}$ & - \\
\hline
\end{tabular}

Note. $\mathrm{N}=729 ; *$ Correlation is significant at $p<0.05$ (2-tailed); ** Correlation is significant at $p<0.01$ (2-tailed); Solitude $=$ Preference for Solitude; Psy-A $=$ Psychological Avoidance; SPI = Spiritualizing; STR $=$ Stress; ANX $=$ Anxiety; DEP $=$ Depression; EUA Superiority $=$ Superiority factor from original American NPI; BR Superiority $=$ Superiority factor from the Brazilian NPI-adapted version.

\section{Validity Study}

Together, Psychological Avoidance and Spiritualizing predict 3\% of the variance in depression $\left(R 2=.03\right.$, adjusted $\left.R 2=.03, F_{(2,726)}=10.74, p<.001\right), 2 \%$ of the variance in anxiety $\left(R 2=.02\right.$, adjusted $\left.R 2=.02, F_{(2,726)}=7.76, p<.001\right)$, and $2 \%$ of the variance in stress $\left(R 2=.02\right.$, adjusted $\left.R 2=.02, F_{(2,726)}=6.88, p=.001\right)$. In each case, the standardized beta weights for Psychological Avoidance and Spiritualizing are significant and consistent with previous research of the SBS-13 (Fox et al., 2017). Beta weights for the predictors consistently oppose each other. Thus, Psychological Avoidance predicts a .16 unit decrease in depression, while Spiritualizing predicts a .19 unit increase in depression. Psychological Avoidance predicts a .11 unit decrease in anxiety, while Spiritualizing predicts a .17 unit increase in anxiety. Psychological Avoidance predicts a .12 unit decrease in stress, while Spiritualizing predicts a .16 unit decrease in stress. However, Psychological Avoidance and Spiritualizing do not significantly predict scores on preference for solitude $\left(F_{(2,726)}=3.54, p=.029\right)$. 
Table 5

Multiple Regression Results Using Psychological Avoidance and Spiritualizing as Predictors of Psychological Distress

\begin{tabular}{lcccc}
\hline Measure & SB Adj. $R^{2}$ & Psy-A $\beta$ & SPI $\beta$ & $F$ \\
DEP & .03 & $-.16^{* * *}$ & $.19 * * *$ & $10.743 * * *$ \\
ANX & .02 & $-.12 * *$ & $.17 * * *$ & $7.762 * * *$ \\
STR & .02 & $-.12 * * *$ & $.16^{* * *}$ & $6.883 * * *$ \\
\hline
\end{tabular}

Note: $\mathrm{N}=729$;

** Significant at $p<0.01 ; * * *$ Significant at $p<0.001 ; \mathrm{SB}=$ Spiritual Bypass; Psy-A = Psychological Avoidance; $\mathrm{SPI}=$ Spiritualizing; $\mathrm{STR}=$ Stress $; \mathrm{ANX}=$ Anxiety; $\mathrm{DEP}=$ Depression $; F=F$-value for the regression model.

\section{Incremental Validity}

For depression and anxiety, Spiritualizing adds a unique and predictive value over and above demographic variables and Superiority (see Tables 4 and 5). In both cases, Spiritualizing adds another $1 \%$ to the explained variance. Proportionally speaking, Spiritualizing adds between 11.1-16.7\% of predictive gain over age, gender, religious affiliation, and Superiority effects. For stress, Spiritualizing adds no significant predictive value over demographic variables or Superiority (see Table 6).

Table 6

Incremental Validity

\begin{tabular}{|c|c|c|c|}
\hline Predictors & $\operatorname{adj} \cdot R^{2}$ & $\Delta$ adj. $R^{2}$ & $\beta$ \\
\hline \multicolumn{4}{|c|}{ Depression as the Dependent Variable } \\
\hline Age, Gender \& R. Affiliation & $.02 * * *$ & $.02 * * *$ & \\
\hline BR_Superiority & $.08 * * *$ & $.06 * * *$ & $.24 * * *$ \\
\hline SPI & $.09 * *$ & $.01 * *$ & $.10 * *$ \\
\hline \multicolumn{4}{|c|}{ Anxiety as the Dependent Variable } \\
\hline Age, Gender \& R. Affiliation & $.03 * * *$ & $.03 * * *$ & \\
\hline BR_Superiority & $.05 * * *$ & $.02 * * *$ & $.14 * * *$ \\
\hline SPI & $.06^{* *}$ & $.01 * *$ & $.10^{* *}$ \\
\hline \multicolumn{4}{|c|}{ Stress as the Dependent Variable } \\
\hline Age, Gender \& R. Affiliation & $.04 * * *$ & $.04 * * *$ & \\
\hline BR_Superiority & $.13 * * *$ & $.09 * *$ & $.30 * * *$ \\
\hline SPI & $.13^{*}$ & $.00^{*}$ & $.08^{*}$ \\
\hline
\end{tabular}

Note. $\mathrm{N}=729$.

*Significant at $p<0.05$; ** Significant at $p<0.01$;*** Significant at $p<0.001$; BR_Superiority $=$ Superiority Factor from the Brazilian NPI adapted version; SPI = Spiritualizing.

\section{Discussion}

In this investigation, we have conducted three studies with the purpose of validating the SBS-13 on a sample of the Brazilian population, testing the effects of age, gender, and religious affiliation on the scores for spiritual bypass and exploring the relationships between spiritual bypass and the measures of psychological distress, preference for solitude, and narcissism. The findings provide evidence of the validity and reliability of the newly revised SBS-BT for use in the Brazilian Portuguese-speaking community to measure spiritual bypass. Our first study shows the scale to have a factorial structure of 
two subscales for this population, as indicated by the CFA. The items on the subscales align with those found on the original version: (a) Psychological Avoidance and (b) Spiritualizing (see Fox et al., 2017). However, we found two major differences between the Brazilian version and the original SBS-13. The first is that Item 1 (My spiritual life helps me feel my emotions more fully) performs poorly, and as such was removed from the translated version of the scale. We have concluded that for the Brazilian sample the meaning of this item was interpreted by the Brazilian sample differently than the American sample. Consistent with Brazilian language and culture, the sample likely interprets the use of spirituality to feel emotions as a way of ultimately not treating affective states realistically by overemphasizing their positive qualities. In this way, the sample would have viewed this particular item, originally written as a reversescored item in the original SBS-13, as more linguistically consistent with the concept of Psychological Avoidance. The second major difference is that we were never able to replicate the second-order factor (called spiritual bypass in the original validation study) in any of our models. Thus, we conclude using a total score for the translated scale to be inappropriate. Once we removed Item 1 from the CFA and tested a twofactor model, fit indices improved substantially. Moreover, alpha coefficients for the adapted version with 12 items are also strong (ranging from .72 to .86).

In our second study, we were able to recover the two-factor structure (again without either Item 1 or the second-order factor) of the SBS-BT. We then tested for structural invariance of the scale by partitioning the sample along lines of group identification, including age (young, middle, and adult), gender (male and female), and religious affiliation (spiritual but not religious and traditional religions). Our results indicate the items from the SBS-BT to have been interpreted consistently between these groups, which had previously been untested even in the original version of the scale (see Fox, et al., 2017). Next, we tested for the possible effects of age in predicting scores for the SBS-BT. We found one factor, Psychological Avoidance, to be linearly associated with age. However, we found no mean group differences when comparing gender, age, and their interactions. However, clarifying that the number of females $(n=601,82.4 \%)$ in our sample is disproportionately higher than the number of males $(n=128,17.6 \%)$ and that the age group from 30 to $60(n=545,74.7 \%)$ is disproportionately higher than the other two age groups, which may have influenced the results, is important. In the second MANOVA, we compared the differences between religious affiliation $(N=729, n=342$, $46.9 \%$ Spiritual but not religious, $n=387,53.1 \%$ traditional religions) on the scores of Psychological Avoidance and Spiritualizing. Univariate analyses indicate that people with traditional religious affiliation score significantly higher $(M=21.23)$ than spiritual but not religious people $(M=19.37)$ on Psychological Avoidance. The same is true for Spiritualizing, as those with a traditional religious affiliation score significantly higher ( $M=8.14)$ than the spiritual but not religious $(M=7.59)$ participants on Spiritualizing. A possible explanation for this can be that traditional religious people may be more attached 
to their beliefs and spiritual practices compare to less traditional people, as spiritual but not religious people tend to combine different types of beliefs and practices. This theory is consistent with previous findings about spiritual bypass and measures of spirituality and religiosity_-spiritual bypass positively correlates with both (Fox et al., 2017).

Finally, in our third study, we tested the relationships between the SBS-BT and measures of psychological distress, preference for solitude, and narcissism. For this purpose, we started by analyzing bivariate correlations to determine relationships between both factors of spiritual bypass to depression, anxiety, stress, Superiority, and preference for solitude. Consistent with previous research (see Fox et al., 2017), results show (see Table 2) Spiritualizing to positively correlate with anxiety, depression, and stress, while Psychological Avoidance negatively correlates to preference for solitude and Superiority. No significant correlation is found between Psychological Avoidance and anxiety, depression and stress or between Spiritualizing with preference for solitude and Superiority. The positive correlations between Spiritualizing and the variables of psychological distress align with our initial hypothesis. However, we didn't expect a negative correlation between Psychological Avoidance and preference for solitude or Superiority. It is possible that when people prefer solitude they are also more willing to directly experience their emotions instead of avoiding them. Two possible explanations exist for why Superiority negatively correlates with Psychological Avoidance. First, though spiritual narcissism is hypothesized as a component of spiritual bypass (Cashwell et al., 2007; Cashwell et al., 2010; Welwood, 2000; Whitfield, 2003), none of the items on the SBS-BT nor in the original version of the scale directly relate to this concept. Second, the internal reliability of the NPI is questionable, rendering the interpretation suspect. The Superiority alpha in our sample for the English version of the scale is .49 (the original scale has an alpha of .54) and .47 for the Brazilian version (the original scale has an alpha of .39). We also tested the predictive capacity of Psychological Avoidance and Spiritualizing on depression, anxiety, stress, and preference for solitude (Table 3). As we had hypothesized, Spiritualizing and Psychological Avoidance are able to predict variance in all three tested variables of psychological distress (varying from $2 \%$ to $3 \%$ ). Consistent with previous research on the SBS-13 (Fox et al., 2017), beta weights for the predictors consistently oppose each other, while Spiritualizing tends to reinforce anxiety, stress, and depression, Psychological Avoidance attenuates all of them. What is unknown, however, is whether Psychological Avoidance attenuates anxiety, stress, and depression, or rather attenuates the experience of these. That is, those who use spirituality in unhealthy ways to avoid their psychological struggles plausibly may be inclined to under-report their psychological distress. Contrary to our hypothesis, Psychological Avoidance and Spiritualizing do not significantly predict scores on preference for solitude. One possible explanation for this finding is that when looking at symptoms or demonstrations of spiritual bypass, some people tend to isolate themselves, while others look for a sense of community (Masters, 2010; Welwood, 2000). The predictive capacity of the SBS-BT remains potent after controlling for age, gender, religious affiliation, and Superiority. For depression and 
anxiety, Spiritualizing adds a unique and predictive value over and above demographic variables or the factor of narcissism (see Tables 4 and 5). These findings reinforce the findings of previous researchers (Fox, et al., 2017). Spiritualizing being associated with unit increases in psychological distress is also a repeated finding. A recent phenomenological study of experts who have had clinical experience with spiritual bypass suggested that avoiding contact with difficult emotions may be an effective short-term coping strategy, but over time the accumulation of repressed emotions can lead to an even deeper existential anguish (Picciotto \& Fox, 2017). Our cross-sectional analysis did find that Psychological Avoidance may increase with age; however, the extent this effect can have on human psychology is open to question.

\section{Clinical Implications}

Although additional research on the SBS-BT is needed to further assess the psychometrics and clinical utility of the measure, results from this study provide initial evidence of the construct validity and reliability of the measure. Accordingly, it may be a useful measure for research and clinical practice. Clinically, the SBS-BT might be useful with clients who present as spiritually oriented but report significant struggles in others aspects of their lives, including careers, relationships, and difficulty with emotions or mood states. The two dimensions of the SBS-BT (Psychological Avoidance and Spiritualizing) do appear to provide clinically nuanced information and should be the primary focus of the therapist, particularly given that the factor structure for the second-order factor (Spiritual Bypass) does not hold together with this sample. Based on the norms for the SBS-BT subscales provided in Table 7, a client's raw scores on the SBS-BT subscales can be easily compared to the norms established in this study, which could in turn be presented to the client as percentile scores, a frame easily understood by many clients. Beyond this, however, even using individual items on the SBS-BT to initiate deeper exploration and therapeutic conversations could prove beneficial for a client.

Table 7

Normative Information for SBS-BT

\begin{tabular}{lccccccc}
\hline \multirow{2}{*}{ Gender } & \multirow{2}{*}{ Age } & \multicolumn{2}{c}{ Psychological-Avoidance } & \multicolumn{2}{c}{ Spiritualizing } & \multicolumn{2}{c}{ Spiritual Bypass } \\
\cline { 2 - 8 } Male & $\mathbf{M}$ & $\boldsymbol{S D}$ & $\boldsymbol{M}$ & $\boldsymbol{S} \boldsymbol{D}$ & $\boldsymbol{M}$ & $\boldsymbol{S} \boldsymbol{D}$ \\
\hline \multirow{3}{*}{ Female } & $\mathbf{1 8 - 2 9}$ & 20.76 & 4.48 & 7.53 & 2.07 & 28.29 & 5.72 \\
& $\mathbf{3 0 - 6 0}$ & 19.51 & 4.44 & 7.64 & 2.08 & 27.15 & 5.89 \\
& $\mathbf{6 1 - 9 4}$ & 22.11 & 6.05 & 8.56 & 2.96 & 30.67 & 8.80 \\
\hline \multirow{3}{*}{ Combined } & $\mathbf{1 8 - 2 9}$ & 20.44 & 4.52 & 8.14 & 2.37 & 28.58 & 6.14 \\
& $\mathbf{3 0 - 6 0}$ & 20.44 & 4.33 & 7.88 & 2.08 & 28.31 & 5.75 \\
& $\mathbf{6 1 - 9 4}$ & 20.92 & 4.42 & 7.76 & 2.10 & 28.68 & 5.84 \\
\hline & $\mathbf{1 8 - 2 9}$ & 20.48 & 4.50 & 8.07 & 2.33 & 28.55 & 6.07 \\
& $\mathbf{6 1 - 9 4}$ & 21.15 & 4.72 & 7.83 & 2.08 & 28.09 & 5.79 \\
\hline
\end{tabular}

Note. Total $N=729 ; n$ for Males $=128 ; n$ for Females $=601 ; n$ for $18-29$ age range $=137 ; n$ for age range $30-60=545 ; n$ for age range 61 to $94=47$. 
How the results of the SBS-BT are integrated into therapy likely depends on the client and will be both variable and nuanced. For some clients, there likely will be resistance to the results and their implications. For example, clients with high scores on the spiritualizing subscale, may have a difficult time understanding the potential shadow side of their spiritualizing because of their convictions and may, in fact, feel threatened and defensive from this notion. Similarly, because spiritual bypass often serves an avoidance function, some clients may be resistant to their results and minimize the negative ways in which they are impacted. In fact, having some clients acknowledge a need for deeper psychological work to be done may psychologically threaten them, which may in turn lead them to defend their spiritualizing or avoidance. Therapists who counter these defenses directly may be at risk of occasioning resistance to the assessment results and the larger therapeutic process.

Accordingly, presenting the assessment results to clients using a Motivational Interviewing (Miller \& Rollnick, 2012) framework might prove useful. Within the MI framework, results of assessments are presented tentatively to clients with an emphasis on empowering clients to give voice to their reactions to findings and possible interpretations. In this way, the therapist can best avoid imposing values or belief systems on the clients and better support clients struggling with spiritual bypass to move from resistance to ambivalence and from ambivalence to change (Clarke, Giordano, Cashwell, \& Lewis, 2013).

However, for other clients who are less entrenched in this avoidance paradigm, the information provided in the subscales of the SBS-BT may create a new lens for looking at their struggles and create openness for change to occur. With this new information, clients may be empowered to explore how their spirituality has served them well and how it has hurt them through a process of compartmentalizing and avoiding their psychological work. Over time, clients may become more integrated in mind, body, spirit, and emotions, the goal in treating spiritual bypass (Cashwell et al., 2004; Masters, 2010; Mathieu, 2011). As a short-term goal, however, simply moving from an implicit and unconscious practice of spiritual bypass to viewing their bypass explicitly and consciously is critical. Furthermore, adopting a non-shaming approach to this work is similarly important. That is, having the therapist help the client see that their spiritual bypass has helped them cope while also looking at the ways in which it has become maladaptive is critical. In other words, the bypass should be honored even as it is being compassionately challenged.

Unfortunately, the treatment of spiritual bypass has received very little attention in the scholarly literature (Masters, 2010). First and foremost, we hope that establishing this translated measure will encourage additional research for informing treatment. Based on limited information, treatment appears to involve understanding the 
function of the bypass and creating individualized treatment plans based on this information. The SBS-BT provides information about whether the function of the bypass is psychological avoidance, spiritualizing, or both. Psychological avoidance is commonly associated with trauma, so trauma assessment and trauma-informed care may be warranted (Clark, Classen, Fourt, \& Shetty, 2015). Clients who struggle with spiritualizing, on the other hand, may benefit from psycho-education related to Pargament's (2001) work on coping, highlighting the collaborative coping strategy as an alternative to spiritual bypass and processing and coaching them on how to begin making these changes. Additionally, the short version of the Serenity Prayer provides a framework for courage to change, serenity to accept and surrender, and wisdom to discern the difference. As a caveat, however, some clients may view the collaborative strategy as evidencing a lack of faith and may be ambivalent or actively resistant to this idea. To effectively work with spiritual bypass, therapists must be culturally sensitive, proceed with care, and honor the client's belief and values system, while listening closely for the client's openness to change.

\section{Limitations and Future Research}

Though the study demonstrates how spiritual bypass relates to diverse demographics, including how scores can vary depending on the type of religious affiliation, nationality, race, ethnicity, or gender of participants, our sample is limited by the lack of age proportionality $(N=729, n=137,18.9 \%$ ages from 18 to $29, n=$ $545,74.7 \%$ ages from 30 to 60 and $n=47,6.4 \%$ ages from 61 to 94$)$ and gender $(N=$ $729, n=601,82.4 \%$ female, $n=128,17.6 \%$ male) in its data collection strategy. Some of the results in the construct validity analysis also were possibly affected by the poor internal consistency of the NPI scale, which could have affected our results regarding the relationship between superiority and spiritual bypass. However, the way the SBS13 was originally developed may also equally and truly not have included items of relevance to facets of narcissism. Though the current studies provide evidence of acceptable reliability and validity of the SBS-BT for use in the Brazilian Portuguesespeaking community, future researchers can investigate the cultural variability of the SBS-13 with samples of other nationalities and languages. The SBS-13 and now the SBS-BT also have an inherent limitation: they utilize self-reporting only for its method of response, relying heavily on the participants to accurately self-appraise and respond honestly. Researchers can consider an alternate observer-rater version of the scale to account for any lack of accurate self-presentation in the results.

\section{Conclusion}

The SBS-13 was developed by Fox et al. (2017) to provide a solid foundation and direction to the social scientific study of spiritual bypass. In the current set of three 
studies, we have successfully (a) recovered the two factors of the SBS-13 in a BrazilianPortuguese speaking population; (b) explored the effects of religious affiliation, age, and gender on levels of Psychological Avoidance and Spiritualizing; and (c) explored the relationship of the newly revised SBS-BT and psycho-social variables, including Depression, Anxiety, Stress, Narcissism and Preference for Solitude. Our studies evidence acceptable reliability and validity of the SBS-BT for use in the Brazilian Portuguese-speaking community. Lastly, the findings of the construct-validity studies provide useful information to further both applied and basic research agendas.

\section{References}

Apóstolo, J., Mendes, A., \& Azeredo, Z. (2006). Adaptation to portuguese of the Depression, Anxiety and Stress Scales (DASS). Revista Latino-Americana de Enfermagem, 14(6), 863-871. http://dx.doi.org/10.1590/S0104-11692006000600006

Borsa, J., Damásio, B., \& Bandeira, D. R. (2012). Adaptação e validação de instrumentos psicológicos entre culturas: Algumas considerações. Paidéia, 22(53), 423-432. http://dx.doi. org/10.1590/S0103-863X2012000300014

Brown, T. A., Chorpita, B. F., Korotitsch, W., \& Barlow, D. H. (1997). Psychometric properties of the Depression Anxiety Stress Scales (DASS) in clinical samples. Behaviour Research and Therapy, 35, 79-89.

Burger, J. M. (1995). Individual differences in preference for solitude. Journal of Research in Personality, 29, 85-108. http://dx.doi.org/10.1006/jrpe.1995.1005

Cashwell, C. S., Bentley, P. B., \& Yarborough, J. P. (2007). The only way out is through: The peril of spiritual bypass. Counseling and Values, 51, 139-148. http://dx.doi.org/10.1002/j.2161007X.2007.tb00071.x

Cashwell, C. S., Clarke, P. B., \& Graves, E. G. (2009). Step by step: Avoiding spiritual bypass in 12-step work. Journal of Addictions \& Offender Counseling, 30, 37-48. http://dx.doi. org/10.1002/j.2161-1874.2009.tb00055.x

Cashwell, C. S., Glosoff, H. L., \& Hammonds, C. (2010). Spiritual bypass: A preliminary investigation. Counseling and Values, 54, 162-174. http://dx.doi.org/10.1002/j.2161007X.2010.tb00014.X

Cashwell, C. S., Myers, J. E., \& Shurts, M. (2004). Using the developmental counseling and therapy model to work with a client in spiritual bypass: Some preliminary considerations. Journal of Counseling \& Development, 82, 403-409. http://dx.doi.org/10.1002/j.1556-6678.2004.tb00327.x

Cheung, G. W., \& Rensvold, R. B. (2002). Evaluating goodness-of-fit indexes for testing measurement invariance. Structural Equation Modeling, 9, 233-255. http://dx.doi.org/10.1207/ S15328007SEM0902_5

Clark, C., Classen, C. C., Fourt, A., \& Shetty, M. (2015). Treating the trauma survivor: An essential guide to trauma-informed care. New York, NY: Routledge, Taylor \& Francis.

Clarke, P. B., Giordano, A. L., Cashwell, C. S., \& Lewis, T. F. (2013). The straight path to healing: Using motivational interviewing to address spiritual bypass. Journal of Counseling and Development, 91, 87-94. http://dx.doi.org/10.1002/j.1556-6676.2013.00075.x 
Fox, J., Caswell, C. S., \& Picciotto, G. (2017). The opiate of the masses: Measuring spiritual bypass and its relationship to spirituality, religion, mindfulness, psychological distress, and personality. Spirituality in Clinical Practice. Advance online publication. http://dx.doi.org/10.1037/scp0000141

Gorsuch, R. L. (1984). Measurement: The boon and bane of investigating religion. American Psychologist, 39(3), 228-236. http://dx.doi.org/10.1037/0003-066X.39.3.228

Gravetter, F., \& Wallnau, L. (2014). Essentials of statistics for the behavioral sciences (8th ed.). Belmont: Wadsworth.

Griffith, J. L. (2010). Religion that heals, religion that harms: A guide for clinical practice. New York: Guilford Press.

Koenig, H. (2012). Overview of the research. In H. Koenig (Ed.), Spirituality and health research (pp. 13-27). West Conshohocken: John Templeton Press.

Langaro, F. N. (2012). As Manifestações do Vazio na Sociedade Contemporânea. (Dissertação de Mestrado), Universidade do Vale do Rio dos Sinos, São Leopoldo-RS.

Lovibond, S. H., \& Lovibond, P. F. (1995). Manual for the Depression Anxiety Stress Scales (2nd ed.). Sydney: Psychology Foundation.

Masters, R. A. (2010). Spiritual bypassing: When spirituality disconnects us from what really matters. Berkeley, CA: North Atlantic Books.

Mathieu, I. (2011). Recovering spirituality: Achieving emotional sobriety in your spiritual practice. Center City, MN: Hazeldon.

Miller, W. R., \& Rollnick, S. (2012). Motivational interviewing: Helping people change (3rd ed.). New York: Guilford.

Pargament, K. (2001). The psychology of religion and coping: Theory, research, practice. New York: Guilford.

Pargament, K. (2011). Spiritually integrated psychotherapy: Understanding and addressing the sacred. New York: Guilford Press.

Picciotto, G., \& Fox, J. (2017). Exploring experts' perspectives of spiritual bypass: A conventional content analysis. Pastoral Psychology. Advance online publication https://oi.org/10.1007/ s11089-017-0796-7

Raskin, R., \& Terry, H. (1988). A principal-components analysis of the Narcissistic Personality Inventory and further evidence of its construct validity. Journal of Personality and Social Psychology, 54(5), 890-902.

Ricoeur, P. (1970). Freud and philosophy: An essay on interpretation. New Haven, CO: Yale University Press.

Testa, M. G., Rohde, L. R., \& Luciano, E. M. (2011). As preferências de estudantes universitários por contato social. Administração: Ensino e Pesquisa, 12(1), 93-118.

Ullman, J. B. (2001). Structural equation modeling. In B. G. Tabachnick \& L. S. Fidell (Eds.), Using multivariate statistics (pp. 653-771). Boston, MA: Allyn \& Bacon.

Welwood, J. (1984). Principles of inner work: Psychological and spiritual. The Journal of Transpersonal Psychology, 16, 63-73.

Welwood, J. (2000). Toward a psychology of awakening: Buddhism, psychotherapy, and the path of personal and spiritual transformation. Boston, MA: Shambhala Publications. 